\title{
BIOAKTIVITAS EKSTRAK METANOL DAUN NAMNAM SERTA KOMBINASINYA DENGAN MADU TRIGONA
}

\section{[Bioactivity of Methanol Extract of Namnam Leaves in Combination with Trigona Honey] \\ La Ode Sumarlin ${ }^{1,2) \star}$, Agik Suprayogi ${ }^{1)}$, Min Rahminiwati ${ }^{1)}$, Achmad Tjachja ${ }^{3)}$, dan Dede Sukandar ${ }^{2}$}

\author{
1) Program Doktor IImu-IImu Faal dan Khasiat Obat, Sekolah Pascasarjana Institut Pertanian Bogor, Bogor \\ 2) Program Studi Kimia, Universitas Islam Negeri Syarif Hidayatullah Jakarta, Tangerang \\ 3) Program Studi Agribisnis, Universitas Islam Negeri Syarif Hidayatullah Jakarta, Tangerang
}

Diterima 28 Mei 2015 / Disetujui 15 September 2015

\begin{abstract}
Namnam (Cynometra cauliflora L) and trigona honey are two potential natural ingredients to be developed in Indonesia. However, scientific evidence of their active compounds and bioactivity is still rarely found, particularly the combination of these two materials. Therefore, this research aimed to explore the active ingredients of the combination of the two materials, i.e. total phenolic, flavonoids, vitamin $C$ and $\beta$ carotene and its bioactive capabilities such as antioxidant activity and antibacterial activity. The analysis showed the methanol extract of Namnam leaves (EMDN) and trigona honey either in their sole form or combined form has antioxidant and antibacterial activity. The EMDN was more active to Staphylococcus aureus $(23.7 \pm 3.3 \mathrm{~mm}$ ) than to Escherichia coli, while the Trigona honey (MT) more active to Escherichia coli $(32.6 \pm 4.4 \mathrm{~mm})$ than Staphylococcus aureus $(16.6 \pm 4.1 \mathrm{~mm})$. Similarly, the combination of EMDN and MT showed higher activity to Escherichia coli $(23 \pm 1.9 \mathrm{~mm})$ than Staphylococcus aureus $(17.6 \pm 2.6 \mathrm{~mm})$. Analysis of the antioxidant activity also showed that EMDN provided the highest activity with an $I C_{50}$ of $0.0048 \pm 0.000 \mathrm{mg} / \mathrm{mL}$ ), while a combined EMDN and MT had an $1 C_{50} 0$ f $0.0085 \pm 0.000 \mathrm{mg} / \mathrm{mL}$ ) and $M T$ with an $I_{50}$ of $3.736 \pm 0.112 \mathrm{mg} / \mathrm{mL}$. Moreover, this analysis also showed that sole samples of MT and EMDN have total phenolic content, flavonoids, and vitamin $C$ that were higher than the combination of MT and EMDN. However, the content of $\beta$-carotene in the combined form of MT and EMDN was higher. Thus trigona honey, methanol extract of leaves Namnam (Cynometra cauliflora L) in a single form or in a combination are potential to be utilized and developed as a source of antioxidants and antibacterial in the form of functional food.
\end{abstract}

Keywords: antib acterial, antioxidant, Cynometra cauliflora L, honey trigona, namnam

\section{ABSTRAK}

Tanaman namnam (Cynometra cauliflora L) dan madu trigona merupakan dua bahan alam yang sangat potensial untuk dikembangkan di Indonesia. Namun informasi ilmiah mengenai bahan aktif dan bioaktivitasnya masih belum banyak diteliti khususnya kombinasi dari kedua bahan tersebut. Oleh karena itu, penelitian ini ditujukan untuk mengeksplorasi bahan aktif kombinasi kedua bahan tersebut seperti total fenolik, flavonoid, vitamin $C$ dan $\beta$-karoten serta kemampuan aktivitas antioksidan dan antibakteri. Hasil analis is menunjukkan bahwa ekstrak metanol daun namnam (Cynometra cauliflora L) dan madu trigona dalam bentuk tunggal maupun bentuk kombinasinya memiliki aktivitas antioksidan dan antibakteri. Aktivitas antibakteri ekstrak metanol daun namnam (EMDN) lebih tinggi terhadap Staphylococcus aureus $(23,7 \pm 3,3 \mathrm{~mm})$ dibandingkan Escherichia coli, sedangkan aktivitas antibakteri madu trigona (MT) lebih tinggi terhadap Escherichia coli $(32,6 \pm 4,4 \mathrm{~mm})$ dibandingkan bakteri Staphylococcus aureus $(16,6 \pm 4,1$ $\mathrm{mm})$. Demikian pula, kombinasi EMDN dan MT lebih kuat terhadap Escherichia coli $(23 \pm 1,9 \mathrm{~mm})$ daripada Staphylococcus aureus $(17,6 \pm 2,6 \mathrm{~mm})$. Analis is terhadap aktivitas antioksidan juga menunjukkan bahwa EMDN memberikan aktivitas tertinggi $\left(\mathrm{IC}_{50} 0,0048 \pm 0,000 \mathrm{mg} / \mathrm{mL}\right)$, kombinasi EMDN dan MT (IC 50 $0,0085 \pm 0,000 \mathrm{mg} / \mathrm{mL})$ dan MT (IC $503,736 \pm 0,112 \mathrm{mg} / \mathrm{mL})$. Selain itu, analisis ini menunjukkan pula sampel MT dan EMDN tunggal memiliki kandungan total fenolik, flavonoid, vitamin $\mathrm{C}$ lebih tinggi dibandingkan kombinasi MT dan EMDN. Namun pada kandungan $\beta$-karoten kombinasi MT dan EMDN lebih tinggi. Dengan demikian, madu trigona, ekstrak metanol daun namnam (Cynometra cauliflora $\mathrm{L}$ ) dalam bentuk tunggal maupun kombinasinya sangat potensial dimanfaatkan dan dikembangkan sebagai sumber antioksidan dan antibakteri dalam suatu bentuk pangan fungsional.

Kata kunci: antibakteri, antioksidan, Cynometra cauliflora L, madu trigona, tanaman namnam 


\section{PENDAHULUAN}

Tanaman namnam (Cynometra cauliflora L) dan madutrigona merupakan dua bahan alam yang sangat potensial untuk dikembangkan di Indonesia. Namun informasi ilmiah tentang aktivitas bioaktifnya masih belum banyak diteliti, khususnya kombinasi dari kedua bahan tersebut. Komponen bioaktif yang dimaksud adalah komponen secara alamiah terdapat dalam bahan pangan dan dapat memberikan manfaat bagi kesehatan (Biesalski et al., 2009).

Hasil penelitian Owayss et al. (2004) dan Ferreira et al. (2009) menunjukkan bahwa pada madu terdapat klorofil, $\beta$-karoten, likopen, karotenoid, dan flavonoid. Bahkan, Ferreira et al. (2009) menyatakan bahwa kandungan $\beta$-karoten dan likopen madu masing-masing sebesar $9,49 \mathrm{mg} / \mathrm{kg}$ dan $6,12 \mathrm{mg} / \mathrm{kg}$. Selain itu, Zainol et al., 2013 juga menyatakan bahwa madu kelulut memiliki potensi sebagai antibakteri. Madu dari lebah stinglessbee bahkan memiliki rasa, aroma dan kekentalan berbeda yang berguna untuk medis dan terapi (Biluca et al., 2014). Madu Trigona spp memiliki total fenolik sekitar $784,3 \mathrm{mg}$ GAE/kg dibandingkan dengan madu Apis spp. sekitar 590,5 mg GAE/kg (Kek et al., 2014). Keberadaan senyawa-senyawa tersebut menunjukkan bahwa madu lokal juga memiliki potensi sebagai anti kanker dan antioksidan (Sumarlin et al., 2014).

Seperti halnya madu, daun tanaman namnam (Cynometra cauliflora L) yang merupakan pohon berbuah dari suku polong-polongan, Leguminosae atau Fabaceae juga telah diteliti oleh Aziz dan Iqbal (2013), terkandung adanya tanin, saponin, flavonoid, terpenoid, dan glikosida yang bermanfaat sebagai antioksidan. Aktivitas antioksidan dalam tanaman Cynometra cauliflora L. ditemukan dalam urutan sebagai berikut: daun muda $>$ daun tua $>$ batang $>$ kulit. Hasil penelitian Ado et al. (2014), juga menunjukkan bahwa ekstrak metanol daun namnam memiliki kadar total fenolik sebesar $214,370 \mathrm{mg}$ GAE/g dan aktivitas antioksidan dengan nilai $I_{50}$ sebesar $0,048 \mathrm{mg} / \mathrm{mL}$. Penelitian lain dari suku golongan Fabaceae sebagai antibakteri diantaranya ekstrak Senna italica yang memiliki daya hambat terhadap bakteri Pseudomonas aeruginosa, Enterococcus faecalis, Escherichia coli dan Staphylococcus aureus (Masoko et al., 2009), ekstrak etil asetat daun jengkol (Pithecolobium lobatum Benth) memiliki aktivitas dalam menghambat pertumbuhan bakteri Staphylococcus aureus dan Escherichia coli (Salni et al., 2011).
Semua publikasi tanaman namnam dan madu trigona tersebut dalam bentuk tunggal. Beberapa publikasi kombinasi madu seperti kombinasi madu dan Nigella sativa (Maslem et al., 2012), kombinasi madu dan Garcinia Kola (Akinnibosun dan Itedjere, 2013), kombinasi madu alam dan benih Peganum harmala (Ahmed et al., 2013), serta kombinasi madu dan tepung kentang (Ahmed et al., 2012) yang telah menghasilkan efek sinergis dan meningkat aktivitasnya. Oleh karena itu, dalam penelitian ini ditujukan untuk mengeksplorasi bahan aktif pada kombinasi bahan ekstrak metanol daun namnam dan madu trigona seperti total fenolik, flavonoid, vitamin $\mathrm{C}$ dan $\beta$-karoten serta kemampuannya sebagai bahan antioksidan dan antibakteri. Hal ini penting untuk mengetahui efek sinergi kedua bahan potensial tersebut secara ilmiah. Untuk mendapatkan hasil yang maksimal, digunakan metode maserasi cara dingin untuk mencegah terurainya metabolit yang tidak tahan pemanasan. Penggunaan pelarut metanol berfungsi melunakkan sel simplisia sehingga senyawa metabolit sekunder yang masih terikat, tertarik ke luar sel dan dilarutkan. Penelitian Suryanto dan Wehantouw (2009) menunjukkan bahwa metanol mampu menarik lebih banyak jumlah metabolit sekunder yaitu senyawa fenolik, flavonoid, dan tanin dalam daun Artocarpus altilis F. dibandingkan dengan etanol. Hasil penelitian Rabeta dan Farazina (2013) pada ekstraksi daun dan buah Garcinia atrovirdis serta buah Cynometra cauliflora dengan menggunakan pelarut metanol memberikan aktivitas antioksidan yang lebih kuat daripada ekstraksi dengan pelarut air. Pada akhirnya, diharapkan penelitian ini dapat digunakan sebagai basis data untuk formulasi antioksidan dan antibakteri kombinasi tanaman namnam dan madu trigona dalam berbagai aplikasi.

\section{BAHAN DAN METODE}

\section{Bahan}

Bahan utama adalah sampel madu trigona yang diperoleh dari peternak lebah di daerah Luwuk Sulawesi Tengah, daun namnam diperoleh dari daerah Pangandaran, Jawa Barat dan diidentifikasi di Herbarium Bogoriense Bidang Botani, Pusat Penelitian Biologi LIPI, Bogor, DPPH (2,2-difenil-1pikril-hidrazil) (Sigma-Aldrich, USA), Escherichia coli ATCC 25922 dan Staphylococcus aureus ATCC 25923 serta bahan-bahan kimia pro analitik lainnya yang diperlukan untuk analisis. 


\section{Ekstraksi daun namnam}

Daun namnam (Cynometra cauliflora L.) dicuci, disortasi lalu dikeringkan dengan sinar matahari selama 30 jam sampai kadar air 9-10\%. Kemudian digiling dengan blender (Arte, Indonesia), sehingga diperoleh serbuk halus. Serbuk daun namnam sebanyak 100 gram direndam dengan $100 \mathrm{~mL}$ methanol (JT Baker, USA) dan dimaserasi selama 24 jam. Setelah itu hasil rendaman disaring dengan kertas saring Whatman No. 4 (Merk milipore, Germany), sehingga diperoleh filtrat yang pertama. Residu daun namnam dimaserasi kembali dengan pelarut methanol selama 9 jam, sehingga diperoleh filtrat yang kedua. Filtrat diuapkan dengan rotary evaporator (Laborata 4000 Heidolph, USA) pada suhu $49^{\circ} \mathrm{C}$ sehingga diperoleh ekstrak kental. Proses ekstraksi dilakukan sebanyak lima kali. Pembuatan formulasi kombinasi madu dan ekstrak metanol daun namnam dilakukan dengan cara menimbang madu dan ekstrak metanol daun namnam dengan menggunakan perbandingan 1:1 (b/b).

\section{Uji alkaloid (uji dragendroff dan bourchardat)}

Sampel sebanyak 0,5 gram ditambah $10 \mathrm{~mL}$ kloroform-amoniak (Merk Milipore, Germany), kemudian disaring. Filtrat ditambahkan dengan 3-5 tetes $\mathrm{H}_{2} \mathrm{SO}_{4} 2 \mathrm{M}$ (Merk Milipore, Germany) dan dikocok sehingga terbentuk dua lapisan. Lapisan asam (terdapat pada bagian atas) dipipet dalam dua tabung reaksi lain, lalu ditambahkan beberapa tetes pereaksi Dragendroff (kombinasi $\mathrm{Bi}\left(\mathrm{NO}_{3}\right)_{2} \cdot 5 \mathrm{H}_{2} \mathrm{O}$ (Merk Milipore, Germany) dalam $\mathrm{HNO}_{3}$ (Merk Milipore, Germany) dan larutan KI (Merk Milipore, Germany) pada tabung A dan pereaksi Bourchardat (4 gram KI (Merk Milipore, Germany) dilarutkan dalam $20 \mathrm{~mL}$ akuades, ditambah 2 gram $\mathrm{l}_{2}$ (Merk Milipore, Germany) ditera hingga $100 \mathrm{~mL}$ ) pada tabung B. Adanya alkaloid ditunjukkan dengan terbentuknya endapan jingga sampai merah coklat (Harborne, 1996).

\section{Uji steroid dan triterpenoid (uji salkowski)} (Harborne, 1996 dengan modifikasi)

Sampel sebanyak 0,5 gram ditambah dengan $20 \mathrm{~mL}$ n-heksana (JT Baker, USA) dan didiamkan selama 2 jam. Kemudian disaring dan ditambahkan $\mathrm{H}_{2} \mathrm{SO}_{4}$ pekat sebanyak 2 tetes (Metode Harborn, 1996 menggunakan kloroform dan asetat anhidrida). Steroid memberikan warna biru atau hijau, sedangkan untuk tritepenoid memberikan warna merah atau ungu.

\section{Uji flavonoid (Harborne, 1996 dengan modifikasi)}

Sampel sebanyak 0,5 gram ditambah dengan $10 \mathrm{~mL}$ air panas (metode Harborne, 1996 menggunakan alkohol), dan didihkan selama 5 menit, kemudian disaring kertas Whatman No. 4. Filtrat sebanyak $5 \mathrm{~mL}$ ditambahkan $\mathrm{HCl}$ pekat (Merk Milipore, Germany) dan 0,05 mg serbuk Mg (Merk Milipore, Germany), kemudian dikocok kuat-kuat. Uji positif ditunjukkan dengan terbentuknya warna merah, kuning, atau jingga.

\section{Uji saponin (uji forth)}

Sampel sebanyak 0,5 gram ditambah air panas sebanyak $5 \mathrm{~mL}$ dalam tabung reaksi dan dikocok. Sampel dinyatakan positif mengandung saponin apabila terdapat busa. Terbentuknya busa yang stabil dalam tabung reaksi menunjukkan adanya senyawa golongan saponin, bila ditambahkan 1 tetes asam klorida $1 \%$ (encer) busa tetap stabil (Djamil dan Anelia, 2009).

\section{Uji tanin atau fenolik}

Sampel sebanyak 0,5 gram ditambah 10 tetes $\mathrm{FeCl}_{3} 1 \%$ (Merk Milipore, Germany). Sampel positif mengandung tannin atau fenol apabila menghasilkan warna hijau, merah, ungu, biru atau hitam pekat (Djamil dan Anelia, 2009).

\section{Uji kuinon}

Sampel sebanyak 0,5 gram ditambah etanol 95\% (Merk Milipore, Germany) sebanyak $2 \mathrm{~mL}$, lalu ditambahkan $\mathrm{NaOH}$ 10\% (Merk Milipore, Germany). Jika terjadi warna kuning, jingga, coklat, atau merah menunjukkan adanya fenolhidrokuinon (Harborne, 1996).

\section{Penentuan aktivitas antioksidan dengan metode DPPH (Singh et al., 2013 dimodifikasi)}

Sebanyak $2 \mathrm{~mL}$ sampel masing-masing dimasukkan ke dalam tabung reaksi, lalu ditambahkan ke dalamnya $2 \mathrm{~mL}$ DPPH 0,002\% (Sigma-Aldrich, USA) (Singh et al., 2013) menggunakan $4 \mathrm{~mL}$ DPPH $0,004 \%$ yang dilarutkan dalam metanol). Kemudian sampel dihomogenkan dan diinkubasi selama 30 menit dalam ruang gelap. Serapan diukur pada panjang gelombang $517 \mathrm{~nm}$ dengan spektrofotometer UV-VIS (Perkin Elmer Lambda 25). Pengukuran dilakukan pengulangan sebanyak 3 kali. Sebagai standar digunakan asam askorbat (Merk Milipore, Germany) pada konsentrasi 0,5; 1; 2; 4 dan $8 \mathrm{ppm}$ dengan perlakuan yang sama dengan sampel uji. Nilai absorbansi yang didapat digunakan untuk menentukan nilai penghambatan sampel melalui perhitungan sebagai berikut: 


$$
\% \text { inhibisi }=\frac{(\text { A blanko-A sampel })}{A \text { blanko }} \times 100 \%
$$

Keterangan:

A blanko = Absorbansi tidak mengandung sampel

A sampel $=$ Absorbansi sampel

Selanjutnya hasil perhitungan dimasukkan ke dalam persamaan regresi sehingga diperoleh nilai $\mathrm{IC}_{50}$ didapat dari perhitungan pada saat persen inhibisi sebesar $50 \%$.

\section{Uji total fenolik (Socha et al., 2009)}

Madu trigona, ekstrak metanol daun namnam, dan kombinasi madu-ekstrak metanol daun namnam (1:1) masing-masing sebanyak 100 mg dilarutkan dalam $10 \mathrm{~mL}$ akuades. Kemudian dipipet sampel sebanyak $0,5 \mathrm{~mL}$ dan ditambahk an $0,3 \mathrm{~mL}$ reagen Folin-Cioucalteu (Merk Milipore, Germany), $2 \mathrm{~mL}$ $\mathrm{Na}_{2} \mathrm{CO}_{3} 15 \%$ (Merk Milipore, Germany) dan ditepatkan dengan akuades hingga volume larutan menjadi $5 \mathrm{~mL}$. Selanjutnya sampel divortex dan diinkubasi selama 2 jam. Sampel diukur serapannya menggunakan spektrofotometer UV-VIS (Perkin Elmer Lambda 25) pada panjang gelombang $750 \mathrm{~nm}$. Kurva standar asam galat (Sigma-Aldrich, USA) dibuat pada deret konsentrasi 10, 20, 40, 60, 80, 100 ppm. Kandungan total fenolik dinyatakan sebagai jumlah ekuivalen mg asam galat (GAE) per 1 gram sampel.

\section{Uji total flavonoid (Meda et al., 2005)}

Madu trigona, ekstrak metanol daun namnam, dan kombinasi (1:1) masing-masing sebanyak 100 mg dilarutkan dalam $10 \mathrm{~mL}$ metanol. Kemudian sampel disaring dan diambil sebanyak $5 \mathrm{~mL}$ dan ditambahkan $5 \mathrm{~mL} \mathrm{AlCl}_{3} 2 \%$ (b/v) (Merk Milipore, Germany). Kemudian sampel dihomogenkan dan diinkubasi selama 10 menit. Sampel diukur serapannya menggunakan spektrofotometer UV-VIS pada panjang gelombang 454,63 $\mathrm{nm}$. Kuersetin sebagai standar dengan deret konsentrasi 10, 20, 30, 40, 50 ppm. Kandungan flavonoid dianggap sebagai jumlah ekuivalen mg kuersetin (QE) (Sigma-Aldrich, USA) per 1 gram sampel.

\section{Uji kadar vitamin C (Ferreira et al., 2009)}

Madu trigona, ekstrak metanol daun namnam, dan kombinasi (1:1) ditimbang sebanyak $100 \mathrm{mg}$ dan diekstraksi dengan $10 \mathrm{~mL} \mathrm{H}_{3} \mathrm{PO}_{4} \quad 1 \%$ (Merk Milipore, Germany). Setelah itu sampel diinkubasi 45 menit pada suhu ruang dan dilanjutkan dengan penyaringan menggunakan kertas Whatman No. 4. Diambil $1 \mathrm{~mL}$ filtrat dan ditambahkan $9 \mathrm{~mL}$ DCPIP
0,005\% (Merk Milipore, Germany). Sampel kemudian dihomogenkan dan diinkubasi selama 30 menit pada suhu ruang. Serapan diukur menggunakan spektrofotometer UV-VIS pada panjang gelombang $519 \mathrm{~nm}$. Sebagai standar digunakan asam askorbat standar dengan deret konsentrasi 10, 20, 40, 80, $100 \mathrm{mg} / \mathrm{L}$ dan menggunakan persamaan regresi. Kandungan vitamin $\mathrm{C}$ dinyatakan sebagai jumlah ekuivalen $\mathrm{mg}$ asam askorbat (AA) per $1 \mathrm{~g}$ sampel.

\section{Uji total kandungan karotenoid (Alvarez-Suarez et al., 2010)}

Uji kandungan total karotenoid dilakukan pada madu trigona dan ekstrak dari daun namnam. Sampel madu sebanyak 1 gram dilarutkan dengan pelarut n-heksana-metanol (1:1) (JT Baker, USA) dishaker (Heidolph Unimax 1010, USA) selama 1 jam dan didiamkan selama 10 menit pada suhu ruang. Kemudian disaring dengan menggunakan kertas saring Whatman No. 4. Filtrat diukur absorbansinya dengan spektrofotometer UV-Vis pada panjang gelombang $450 \mathrm{~nm}$. Sebagai standar digunakan $\beta$-karoten (Sigma-Aldrich, USA) dengan kurva standar pada konsentrasi $(0,015-0,6 \mu \mathrm{g} / \mathrm{mL})$. Total kandungan karotenoid dinyatakan dalam $\mathrm{mg}$ setara dengan $\beta$-karoten (mg $\beta C E / g$ ). Diulang dengan menggunakan ekstrak madu dan daun namnam dan hasil partisi $n$-heksana, etil asetat dan butanol.

\section{Pengujian antibakteri dengan metode zona bening (Lestari et al., 2013)}

Sebanyak $1 \mathrm{~mL}$ inokulum bakteri uji fase midlog diambil kemudian dimasukkan ke dalam $100 \mathrm{~mL}$ media MHA (Merk Milipore, Germany) dan dihomogenkan. Selanjutnya media yang berisi inokulum tersebut dituang ke dalam cawan petri dan dibiarkan memadat. Sebanyak $0,1 \mathrm{~mL}$ baik sampel maupun kontrol yang telah dipersiapkan di dalam syringe dituangkan pada agar yang telah dilubangi dengan sedotan steril. Kemudian petri ditutup kembali segera, setelah itu diinkubasi selama 18-24 jam pada suhu $37^{\circ} \mathrm{C}$. Diukur zona hambat dari masing-masing sampel kemudian dibandingkan dengan kontrol positif. Untuk setiap perlakuan dilakukan tiga kali pengulangan (triplo).

\section{Analisis data}

Analisis data dilakukan sebanyak triplo dan data yang ditampilkan berupa mean \pm standar deviasi. Hasil uji fitokimia dianalisis secara deskriptif sedangkan aktivitas antioksidan, kadar total fenolik, total flavonoid, dan vitamin $\mathrm{C}$ dianalisis secara statistik menggunakan Analisis Variansi (ANOVA) 
satu arah (One Way) dengan batas kepercayaan 95\% (a 0,05) menggunakan Statistical Package for the Social Sciences (SPSS) versi 20 (Latuconsina et al., 2014).

\section{HASIL DAN PEMBAHASAN}

\section{Hasil uji fitokimia}

Rendemen ekstrak yang diperoleh dalam penelitian ini bervariasi sebesar $6,16 \%$ hingga $9,41 \%$ (Tabel 1). Nilai rendemen ini dapat digunakan untuk mengetahui nilai ekonomis suatu produk atau bahan. Rendemen ekstrak dalam penelitian ini bervariasi disebabkan oleh ketidakseragaman ukuran partikel pada satuan mesh tertentu setelah digiling dan pengayakan goyang. Hasil ini akan digunakan untuk uji-uji selanjutnya termasuk uji fitokimia.

Tabel 1. Rendemen ekstrak metanol daun namnam dalam beberapa pengulangan

\begin{tabular}{cccc}
\hline Maserasi $^{*}$ & $\begin{array}{c}\text { Berat } \\
\text { Sampel } \\
\text { Serbuk (g) }\end{array}$ & $\begin{array}{c}\text { Berat } \\
\text { Ekstrak (g) }\end{array}$ & $\begin{array}{c}\text { Rendemen } \\
(\%)\end{array}$ \\
\hline I & 100 & 7,55 & 7,55 \\
II & 100 & 6,19 & 6,19 \\
III & 100 & 6,16 & 6,16 \\
IV & 100 & 6,30 & 6,30 \\
V & 100 & 6,85 & 6,85 \\
VI & 100 & 9,41 & 9,41 \\
\hline
\end{tabular}

Keterangan: ${ }^{*}$ I, II, III, IV, V dan VI adalah pengulangan untuk mendapatkan sampel yang akan diuji selanjutnya

Analisis fitokimia dilakukan untuk memberikan gambaran tentang golongan senyawa yang terkandung dalam Madu Trigona (MT) dan Ekstrak Metanol Daun Namnam (EMDN) secara tunggal maupun kombinasi (EMDN : MT). Hasil pengujian memperlihatkan bahwa semua jenis sampel baik tunggal maupun kombinasi positif mengandung senyawa fenolik dan flavonoid (Tabel 2). Hasil uji fitokimia terhadap ekstrak metanol daun namnam Positif mengandung fenolik, flavonoid, steroid/ triterpenoid, saponin, dan kuinon (Tabel 2). Hasil ini sesuai dengan penelitian Aziz dan lqbal (2013), penentuan kandungan awal senyawa fitokimia menunjukkan bahwa adanya tanin, saponin, flavonoid, terpenoid, dan glikosida yang bermanfaat sebagai antioksidan pada daun namnam (Cynometra cauliflora).

Pada awalnya MT tidak mengandung steroid/triterpenoid, saponin, dan kuinon, namun setelah kombinasi dengan EMDN menunjukkan hasil fitokimia yang positif (Tabel 2). Hal ini mengindikasikan bahwa kandungan golongan senyawa saponin, kuinon, terpenoid dan steroid berasal dari ekstrak daun namnam. Artinya bahwa kombinasi dua bahan ini saling melengkapi yang dapat menambah nilai aktivitas dari bahan kombinasi.

\section{Aktivitas antioksidan}

Hasil analisis memperlihatkan bahwa semua sampel yang dianalisis memiliki kemampuan melakukan penghambatan terhadap radikal DPPH. Aktivitas antioksidan tertinggi terdapat pada sampel EMDN dengan nilai $I_{50}$ sebesar $0,0048 \mathrm{mg} / \mathrm{mL}$ (Tabel 3). Keberadaan senyawa-senyawa seperti fenolik, flavonoid, dan vitamin C pada madu dan namnam berperan penting untuk aktivitas antioksidan. Hal ini ditunjukkan oleh pola hubungan kandungan senyawa tersebut dengan aktivitas antioksidan (Tabel 4). Hubungan ini memperlihatkan bahwa tingginya kadar fenolik, flavonoid dan vitamin $C$ pada sampel menyebabkan tingginya aktivitas antioksidan (Tabel 4). Hal ini dipertegas oleh hasil penelitian Ado et al. (2014), yang melaporkan kandungan total fenolik dari ekstrak metanol daun tanaman namnam sebesar 214,370 mg GAE/g ekstrak dan aktivitas antioksidan dengan nilai $\mathrm{IC}_{50}$ sebesar $0,048 \mathrm{mg} / \mathrm{mL}$.

Tabel 2. Hasil uji fitokimia sampel ekstrak metanol daun namnam sebelum dan sesudah dikombinasikan dengan madu trigona

\begin{tabular}{lcccccc}
\hline \multicolumn{1}{c}{ Sampel } & Fenolik & Flavonoid & Alkaloid & Steroid/Triterpenoid & Saponin & Kuinon \\
\hline EMDN & + & + & - & + & + & + \\
MT & + & + & - & - & - & - \\
EMDN : MT $(1: 1)$ & + & + & - & + & + & + \\
\hline
\end{tabular}

Keterangan: (+): Terdeteksi; (-): Tidak Terdeteksi; EMDN : Ekstrak Metanol Daun Namnam; MT : Madu Trigona; MT : EMDN (1:1): Kombinasi Madu Trigona : Ekstrak Metanol Daun Namnam (1:1) 
Tabel 3. Aktivitas antioksidan sampel ekstrak metanol daun namnam dan madu trigona sebelum dan setelah kombinasi

\begin{tabular}{lc}
\hline \multicolumn{1}{c}{ Sampel } & $\mathrm{IC}_{50}(\mathrm{mg} / \mathrm{mL})$ \\
\hline Standar vitamin C & $0,0036 \pm 0,000^{\mathrm{a}}$ \\
MT & $3,736 \pm 0,112^{\mathrm{b}}$ \\
EMDN & $0,0048 \pm 0,000^{\mathrm{a}}$ \\
MT : EMDN (1:1) & $0,0085 \pm 0,000^{\mathrm{a}}$ \\
\hline Keterangan: Nilai yang diikuti oleh huruf yang sama pada \\
tabel menunjukkan nilai tidak berbeda nyata (uji \\
Duncan $\alpha=5 \%) ;$ MT: Madu Trigona; EMDN: Ekstrak \\
Metanol Daun Namnam; MT : EMDN (1:1): Kombinasi \\
Madu Trigona : Ekstrak Metanol Daun Namnam (1:1)
\end{tabular}

Ado et al. (2014) juga menyatakan bahwa terdapat 18 senyawa yang telah diidentifikasi dari fraksi aktif etil asetat dan butanol daun Cynometra cauliflora $\mathrm{L}$ yang merupakan bagian dari senyawa fenolik dan flavonoid. Ketika sampel MT dan EMDN dikombinasikan menunjukkan perubahan yang signifikan terhadap aktivitas antioksidan meskipun tidak sebesar EMDN sebelum dikombinasikan. Hasil ini diperkuat oleh hasil analisis statistika yang menunjukkan bahwa aktivitas antioksidan sebelum dan sesudah kombinasi berbeda nyata. Aktivitas antioksidan pada sampel setelah kombinasi diduga diakibatkan oleh keberadaan senyawa aktif yang terdeteksi pada uji fitokimia (Tabel 2) maupun uji kuantitatif (Tabel 4).

Tabel 4. Kandungan total fenolik, flavonoid, dan vitamin C madu trigona dan ekstrak metanol daun namnam sebelum dan setelah kombinasi

\begin{tabular}{lccc}
\hline Sampel & $\begin{array}{c}\text { Kadar Total } \\
\text { Fenolik } \\
\text { (mg GAE/g } \\
\text { Sampel } \\
\pm \text { SD) }\end{array}$ & $\begin{array}{c}\text { Kadar Total } \\
\text { Flavonoid } \\
\text { (mg QE/g } \\
\text { Sampel } \\
\pm \text { SD) }\end{array}$ & $\begin{array}{c}\text { Kadar } \\
\text { Vitamin C } \\
\text { (mg AA } / g \\
\text { Sampel } \\
\pm \text { SD) }\end{array}$ \\
\hline MT & $1,0096 \pm$ & $0,0962 \pm$ & $49,7352 \pm$ \\
& $0,1170^{\mathrm{a}}$ & $0,00490^{\mathrm{a}}$ & $1,43334^{\mathrm{b}}$ \\
EMDN & $267,6897 \pm$ & $12,5850 \pm$ & $201,6848 \pm$ \\
& $7,27079^{\mathrm{c}}$ & $0,17950^{\mathrm{c}}$ & $14,86620^{\mathrm{e}}$ \\
MT : & $131,7105 \pm$ & $6,9388 \pm$ & $61,9637 \pm$ \\
EMDN & $4,66267^{\mathrm{b}}$ & $0,35035^{\mathrm{b}}$ & $1,42908^{\mathrm{c}, \mathrm{d}}$ \\
$(1: 1)$ & & &
\end{tabular}

Keterangan: Nilai yang diikuti oleh huruf yang sama pada tabel menunjukkan nilai tidak berbeda nyata (uji Duncan $\alpha=5 \%$ ); MT: Madu Trigona; EMDN: Ekstrak Metanol Daun Namnam; MT : EMDN (1:1): Kombinasi Madu Trigona : Ekstrak Metanol Daun Namnam (1:1)

Hal ini terlihat dari keberadaan total fenolik, flavonoid dan vitamin $\mathrm{C}$ yang mempengaruhi mekanisme radikal DPPH scavenging. Selain itu, flavonoid juga telah dilaporkan berpengaruh pada sifat antioksidan melalui aktivitas scavenging dan kelating.

Hasil analisis sifat antioksidan $\left(\mathrm{LC}_{50}\right)$ (Tabel 3) pada kombinasi MT dan EMDN tidak menunjukkan nilai yang paling tinggi. Hal ini sejalan dengan fluktuasi total fenolik, flavonoid dan vitamin $\mathrm{C}$. Kondisi ini memperkuat alasan bahwa kemampuan antioksidan kombinasi MT dan EMDN dipengaruhi oleh keberadaan total fenolik, flavonoid dan vitamin C. Pengaruh senyawa ini telah disimpulkan oleh Singh et al., 2010 melalui kombinasi Triphala dengan Terminalia chebula, Terminalia Bellerica dan Emblica officinalis. Penelitian tersebut menyatakan bahwa fraksi yang kaya polifenol relatif berpengaruh terhadap sifat antioksidan dibandingkan yang lebih rendah kadar fenoliknya. Dugaan lain yang mempengaruhi aktivitas antioksidan bahan kombinasi tersebut adalah komposisi bahan. Liu et al., 2014 melakukan penelitian kombinasi ekstrak ubi jalar manis dengan polifenol tanaman Teh dan flavonoid Pueraria yang menyatakan bahwa komposisi bahan yang optimum berperan penting pada kondisi oksidatif sistim biologi. Kondisi ini juga memunculkan dugaan bahwa telah terjadi interaksi senyawa yang terdapat dalam bahan yang dikombinasikan. Meskipun demikian, mekanisme peranan fitokonstituen yang berbeda pada bahan campuran dan mempengaruhi aktivitas antioksidan perlu diteliti lebih lanjut.

Perbedaan sifat antioksidan tidak hanya berkorelasi dengan jumlah total antioksidan, tetapi berkenaan juga dengan komponen-komponen yang terpilih. Secara rinci dikatakan bahwa perbedaan kemampuan sebagai antiradikal (antioksidan) diakibatkan karena (i) perbedaan komponen dan komposisi bioaktif, (ii) keragaman karakteristik struktural fenolik yang berpotensi sebagai antioksidan, (iii) sinergisme komponen bioaktif yang ada dalam setiap kombinasi dan (iv) perbedaan sifat kinetik antioksidan potensial (Ramadan, 2008).

Semua sampel yang ada baik dalam bentuk tunggal maupun campuran menunjukkan nilai $\mathrm{IC}_{50}$ kurang dari 50 ppm. Menurut Jun et al. (2003), aktivitas antioksidan digolongkan sangat aktif jika nilai $I_{50}$ kurang dari 50 ppm, digolongkan aktif bila nilai $I_{50}$ antara 50-100 ppm, digolongkan sedang bila nilai $I_{50}$ 101-250 ppm, dan digolongkan lemah bila nilai $I_{50}$ 250-500 ppm, serta digolongkan tidak aktif bila nilai $\mathrm{IC}_{50}$ lebih besar dari 500 ppm. Semakin kecil nilai $\mathrm{IC}_{50}$ berarti semakin tinggi aktivitas antioksidan. Oleh karena itu, nilai $\mathrm{IC}_{50}$ sampel yang dianalisis menunjukkan kemampuan antioksidan sangat aktif. 


\section{Uji fitokimia dan identifikasi $\beta$-karoten}

Hasil uji fitokimia (Tabel 5) menunjukkan adanya kandungan senyawa golongan triterpenoid dan karotenoid. Senyawa golongan triterpenoid ditandai dengan timbulnya warna merah sedangkan senyawa golongan steroid ditandai dengan terbentuknya warna hijau. Selain itu, uji kualitatif karotenoid dengan menggunakan pereaksi Carr Price ( $\mathrm{SbCl}_{3}$ dalam kloroform). Terbentuknya warna merah jingga atau coklat setelah penambahan $\mathrm{SbCl}_{3}$ menunjukkan dalam ekstrak terdapat karotenoid. Terbentuknya warna merah disebabkan karotenoid membentuk komplek dengan ion logam Sb.

Tabel 5. Hasil uji kualitatif (Scan $\lambda_{\text {Maks }}$ ) keberadaan senyawa karotenoid dan steroid/triterpenoid pada sampel madu trigona dan ekstrak metanol daun namnam

\begin{tabular}{lccc}
\hline \multirow{2}{*}{ Sampel } & \multicolumn{2}{c}{ Golongan Senyawa } & \multirow{2}{*}{$\begin{array}{c}\lambda_{\text {maks }} \\
\text { MT }\end{array}$} \\
\cline { 2 - 4 } EMDN & Steroid/Triterpenoid & Karotenoid & $(\mathrm{nm})$ \\
\hline & + & + & 442,83 \\
& + & + & 328,$37 ;$ \\
& & 382,$20 ;$ \\
& & 418,$81 ;$ \\
& & 443,$68 ;$ \\
& & 472,30 \\
\hline
\end{tabular}

Keterangan: + (Terdeteksi), dan - (Tidak terdeteksi) Madu

Trigona (MT), Ekstrak Metanol Daun Namnam (EMDN)

Hasil scan $\lambda_{\text {maks }}$ (Tabel 5) sampel MT dan EMDN menunjukkan serapan maksimum pada panjang gelombang tertentu (Tabel 5). Hasil ini diperkuat oleh Britton et al. (2004) yang menyatakan bahwa serapan maksimum $\beta$-karoten pada panjang gelombang 425, 450, dan $477 \mathrm{~nm}$. Hal ini menggambarkan bahwa sampel MT dan EMDN memiliki kandungan $\beta$-karoten, selisih jarak panjang gelombang yang berdekatan. Pada sampel ekstrak daun namnam terdapat banyak serapan maksimum, karena adanya senyawa lain yang terdapat pada sampel. Analisis ini menggunakan standar $\beta$-karoten murni sebagai standar pengukuran. Hasil merujuk pada penelitian Alvarez-Suarez et al. (2010) dan Biswas et al. (2011) dengan menggunakan spektrofotometer UV-Vis.

Kandungan $\beta$-karoten pada ekstrak daun namnam $1,013 \mathrm{mg} \quad \beta C E / \mathrm{gr}$ lebih besar jika dibandingkan dengan sampel madu trigona (Tabel 6). Hasil ini diakibatkan oleh pengaruh klorofil terutama pada bagian permukaan atas daun dan keberadaan senyawa polifenol. Lisiewska et al. (2006) menyatakan bahwa tanaman memiliki kandungan karotenoid dan $\beta$-karoten lebih tinggi pada tanaman yang memiliki kandungan klorofil dan polifenol yang tinggi.
Kandungan $\beta$-karoten tersebut akan mengalami peningkatan (Tabel 6) ketika MT dan EMDN dikombinasikan. Hal ini menunjukkan bahwa pemanfaatan kombinasi kedua bahan tersebut sangat potensial untuk mendapatkan fungsi yang terkandung dalam $\beta$-karoten.

Tabel 6. Kadar $\beta$-karoten pada sampel madu trigona dan ekstrak metanol daun namnam sebelum dan setelah dikombinasikan serta ekstraksi partisi pada beberapa pelarut

\begin{tabular}{lc}
\hline \multicolumn{1}{c}{ Sampel } & $\begin{array}{c}\text { Kadar } \beta \text {-karoten } \\
(\mathrm{mg} \beta \text { CE/gr })\end{array}$ \\
\hline MT & $0,014 \pm 0,100$ \\
EMDN & $1,013 \pm 0,020$ \\
MT: EMDN (1:1) & $3,15 \pm 0,500$ \\
Fraksin-heksana & $18,83 \pm 0,030$ \\
Fraksi etil asetat & $0,022 \pm 0,120$ \\
Fraksi butanol & - \\
Fraksiair & -
\end{tabular}

Fraksi air

Keterangan: MT:Madu Trigona, EMDN:Ekstrak Daun Namnam, MT:EMDN (Kombinasi Madu Trigona \& Ekstrak Daun Namnam). Data partisi pada beberapa pelarutuntuk sampel setelah kombinasi (MT : EMDN)

Hasil ini akan mengalami peningkatan lagi ketika sampel kombinasi diekstraksi partisi dengan fraksi n-heksana yang menyebabkan peningkatan kadar $\beta$-karoten hingga mencapai 6 (enam) kali dibandingkan sebelum kombinasi. Penyebab peningkatan kadar $\beta$-karoten ini ditinjau dari struktur dan sifat $\beta$-karoten, termasuk golongan karetonoid yang bersifat non-polar, sehingga mudah larut dalam pelarut non-polar sesuai dengan prinsip like disolves like. Sementara itu, pada fraksi etil asetat relatif sedikit $\beta$-karoten yang terdeteksi pada pelarut ini, karena etil asetat merupakan pelarut semi polar. Akibatnya, $\beta$-karoten yang terekstrak pada fraksi etil asetat relatif lebih sedikit.

\section{Aktivitas antibakteri}

Hasil analisis terhadap aktivitas antibakteri pada semua sampel menunjukkan adanya pembentukkan zona bening, namun dengan intensitas yang berbeda-beda. EMDN menunjukkan zona bening yang paling tinggi pada Staphylococcus aureus, tapi sampel MT paling tinggi pada Escherichia coli (Tabel 8).

Perbedaan respon bakteri dapat disebabkan oleh faktor-faktor yang ada dalam sampel tersebut. Misalnya perbedaan zona hambat sampel MT terhadap kedua bakteri tersebut disebabkan karena perbedaan dinding sel $E$. coli yang memiliki dinding sel yang lebih tipis dibanding $S$. aureus. Peranan dinding sel ini oleh Fadhilla et al. (2012) dinyatakan 
dalam penelitian ekstrak etanol lumut hati bahwa sensitivitas $S$. aureus ATCC 5923 yang tinggi disebabkan karena struktur dinding selnya. Bakteri Gram positif seperti $S$. aureus tidak memiliki membran luar seperti yang dimiliki kebanyakan bakteri Gram negatif. Disamping itu $S$. aureus memiliki dinding sel yang bersifat hidrofobik pada bagian luarnya, sehingga konsentrasi rendah dari ekstrak lumut $(<1 \mathrm{mg} / \mathrm{mL})$ akan dapat membunuh seluruh bakteri S. aureus (Madigan et al., 2009).

Senyawa fenolik akan merusak sel bakteri dengan cara mengubah permeabilitas membran sitoplasma karena larut lemak. Sementara dalam konsentrasi yang lebih rendah, fenol menginaktifkan sistem enzim penting dalam sel bakteri (Oliver et al., 2001). Madu kelulut dari Trigona spp memiliki kandungan fenolik dan intensitas warna yang lebih tinggi dari madu Apis spp (Kek et al., 2014). Aktivitas antibakteri pada madu dapat disebabkan konsentrasi gula yang tinggi, keasaman, total flavonoid, total fenol, konsentrasi hidrogen peroksida atau komponen yang belum teridentifikasi lainnya yang terdapat di dalam madu (Bogdanov, 2015). Keberadaan senyawa fenolik dan flavonoid pada sampel MT dan EMDN yang diuji telah mendukung beberapa pernyataan sebelumnya (Tabel 4).

Pengujian antibakteri ekstrak metanol daun namnam (EMDN) menunjukkan bahwa zona hambat $S$. aureus sebesar $23,7 \mathrm{~mm}$, sedangkan $E$. coli tidak membentuk zona hambat (Tabel 7). Senyawa aktif yang berperan sebagai antibakteri pada daun namnam hampir sama dengan senyawa aktif yang terkandung di dalam MT, hanya saja kadar senyawa aktif tersebut yang berbeda, sehingga memberikan pengaruh yang berbeda pula pada kedua bakteri. Total fenolik dan flavonoid pada ekstrak metanol daun namnam cukup tinggi dibandingkan dengan madu, namun senyawa aktif ekstrak metanol daun namnam hanya mampu menghambat pertumbuhan $S$. aureus yang disebabkan dinding selnya bersifat polar, sehingga senyawa aktif ekstrak metanol daun namnam yang bersifat polar juga lebih mudah menembus dinding sel $S$. aureus tersebut.

Sampel EMDN dapat menghambat pertumbuhan $S$. aureus karena bakteri tersebut tidak memiliki membran luar seperti E. coli. S.aureus hanya memiliki dinding sel yang terdiri dari lapisan peptidoglikan tanpa adanya tiga polimer pembungkus di luar sehingga selnya akan mudah terdenaturasi oleh senyawa aktif di dalam ekstrak metanol daun namnam. Sebaliknya, E. coli memiliki tiga lapisan dinding sel yang menyebabkan bakteri tersebut lebih tahan terhadap ekstrak metanol daun namnam. Senyawa fenolik yang memiliki substansi cincin aromatik dengan satu atau lebih gugus hidroksil sehingga dapat menembus peptidoglikan. Akibatnya, dinding dan membran sel mengalami kerusakan dan mengganggu sistem transpor aktif bakteri (Bachir dan Benali, 2012). Menurut Ruiz et al. (2012) senyawa fenolik selain merusak struktur dinding sel dan mengganggu kerja transpor aktif, juga mengganggu kekuatan proton di dalam membran sitoplasma bakteri. Kemampuan antibakteri tanaman dari jenis cynometra yang lebih besar pada $S$. aureus dibandingkan $E$. coli ini dipertegas oleh beberapa penelitian seperti pada ekstrak etanol daun Cynometra travancorica (John et al., 2012) dan ekstrak methanol kulit kayu Cynometra ramiflora Linn (Afjalus et al., 2013).

Tabel 7. Pengaruh ekstrak tunggal dan kombinasi MT dan EMDN terhadap penghambatan pertumbuhan Staphylococcus aureus dan Escherichia coli

\begin{tabular}{lcc}
\hline \multicolumn{1}{c}{ Sampel } & $\begin{array}{c}\text { Staphylococcus } \\
\text { aureus } \\
(\mathrm{mm} \pm \mathrm{SD})\end{array}$ & $\begin{array}{c}\text { Escherichia } \\
\text { coli } \\
(\mathrm{mm} \pm \mathrm{SD})\end{array}$ \\
\hline EMDN & $23,7 \pm 3,3^{\mathrm{d}}$ & $0,00 \pm 0,00^{\mathrm{a}}$ \\
MT & $16,6 \pm 4,1^{\mathrm{c}, \mathrm{d}}$ & $32,6 \pm 4,4^{\mathrm{d}, \mathrm{e}, \mathrm{t}, \mathrm{g}}$ \\
MT:EMDN $(1: 1)$ & $17,6 \pm 2,6^{\mathrm{d}}$ & $23 \pm 1,9^{\mathrm{c}}$ \\
Kloramfenikol & $22,2 \pm 3,8^{\mathrm{d}}$ & $27,9 \pm 0,5^{\mathrm{c}, \mathrm{d}, \mathrm{e}}$ \\
Povidone iodine & $10,3 \pm 1,0^{\mathrm{b}, \mathrm{c}}$ & $23,5 \pm 8,9^{\mathrm{c}}$ \\
Metanol & $0,00 \pm 0,00^{\mathrm{a}}$ & $10,8 \pm 3,8^{\mathrm{b}}$ \\
Aquades & $0,00 \pm 0,00^{\mathrm{a}}$ & $0,00 \pm 0,00^{\mathrm{a}}$ \\
\hline
\end{tabular}

Keterangan: Angka-angka yang didampingi oleh huruf yang sama dalam satu kolom menunjukkan tidak berbeda nyata pada taraf uji lanjut Duncan $5 \%$ taraf signifikan $95 \%(P<0,05)$. Data pada perlakuan telah dikonversi terhadap zona hambatoleh metanol

Hasil pengujian antibakteri selanjutnya melalui kombinasi MT dan EMDN menunjukkan bahwa baik pada $E$. coli maupun $S$. aureus menunjukkan adanya zona hambat (Tabel 7). Hasil ini menunjukkan adanya penurunan dibandingkan pada saat sampel tunggal. Selanjutnya pembentukan zona hambat pada $E$. coli sampel kombinasi yang sebelumnya tidak nampak pada EMDN menunjukkan kontribusi hambatan berasal dari sampel MT.

Zona hambat pada kombinasi lebih kecil dibandingkan dengan sampel tunggal. Maslem et al. (2012) menyatakan bahwa kombinasi dua atau lebih substansi akan memberikan nilai medis yang lebih baik jika komponen-komponen di dalamnya tidak terjadi reaksi yang dapat merugikan kesehatan. Selain itu, kecilnya daya hambat ini menunjukkan bahwa komposisi MT dan EMDN (1:1) bukanlah komposisi yang optimal untuk mendapatkan efek antibakteri yang maksimal. Hal ini telah dibuktikan 
melalui penelitian kombinasi madu dan Nigella sativa (Maslem et al., 2012), kombinasi madu dan Garcinia kola (Akinnibosun dan Itedjere, 2013), dan kombinasi madu alam dan benih Peganum harmala (Ahmed et al., 2013), madu dan tepung kentang (Ahmed et al., 2012). Hasilnya menunjukkan bahwa jika komposisi bahan yang dicampurkan dengan madu berbeda maka zona hambat yang dihasilkan cenderung berbeda terhadap masing-masing bakteri uji dan menunjukkan efek sinergi. Bahkan pada beberapa kondisi makin tinggi komposisi yang dicampurkan dengan madu maka zona hambat makin tinggi (Maslem et al., 2012; Akinnibosun dan Itedjere, 2013).

Hasil analisis ini menunjukkan pula bahwa peningkatan komposisi komponen EMDN menyebabkan peningkatan zona hambat. Mekanisme aktivitas antibakteri madu yang kompleks ini diduga berkaitan dengan aktivitas sinergis antara berbagai bahan bioaktif seperti polifenol dan flavonoid (Escuredo et al., 2012; Lee et al., 2008) yang juga terdapat pada MT dan EMDN. Selain itu, kombinasi MT dan EMDN dalam penelitian ini masih menghasilkan zona hambat yang lebih tinggi dibandingkan dengan antibakteri komersil (Povidine lodine) (Tabel 7), sehingga masih sangat potensial untuk tetap dikembangkan sebagai salah satu alternatif antibakteri pada berbagai bahan pangan.

\section{KESIMPULAN}

Analisis ini menunjukkan bahwa sampel MT dan EMDN tunggal memiliki kandungan total fenolik, flavonoid, vitamin C lebih tinggi dibandingkan kombinasi MT dan EMDN. Namun, kandungan $\beta$ karoten kombinasi MT dan EMDN menunjukkan hasil yang lebih tinggi. Analisis terhadap aktivitas antioksidan menunjukkan bahwa EMDN memberikan aktivitas tertinggi $\left(\mathrm{IC}_{50} 0,0048 \pm 0,000 \mathrm{mg} / \mathrm{mL}\right)$, kombinasi EMDN dan MT $\left(\mathrm{IC}_{50} \quad 0,0085 \pm 0,000\right.$ $\mathrm{mg} / \mathrm{mL})$ dan $\mathrm{MT}\left(\mathrm{IC}_{50} 3,736 \pm 0,112 \mathrm{mg} / \mathrm{mL}\right)$. Analisis bioaktivitas sebagai antibakteri juga menunjukkan bahwa EMDN lebih peka terhadap $S$. aureus $(23,7 \pm 3,3 \mathrm{~mm})$ dibandingkan pada $E$. coli, sedangkan MT lebih peka terhadap $E$. coli $(32,6 \pm 4,4 \mathrm{~mm})$ dibandingkan bakteri $S$. aureus $(16,6 \pm 4,1 \mathrm{~mm})$. Demikian pula, kombinasi EMDN dan MT lebih peka terhadap $E$. coli $(23 \pm 1,9 \mathrm{~mm})$ daripada $S$. aureus $(17,6 \pm 2,6 \mathrm{~mm})$. Dengan demikian madu trigona, ekstrak metanol daun namnam (Cynometra cauliflora L) dalam bentuk tunggal maupun kombinasinya sangat potensial dimanfaatkan sebagai sumber antioksidan dan antibakteri dalam suatu bentuk pangan fungsional. Namun demikian, perlu dilakukan penelitian lebih lanjut dengan perbandingan yang berbeda-beda.

\section{UCAPAN TERIMA KASIH}

Terima kasih kepada semua pihak yang telah membantu riset ini dan khususnya kepada almarhumah Dr. Nastiti Kusumorini yang telah melakukan pembimbingan hingga penelitian tahap ini dapat terlaksana dengan baik. Ucapan terima kasih juga saya sampaikan kepada Hilyatuzzahrah yang telah membantu melakukan pengeditan terhadap beberapa bagian dari tulisan ini.

\section{DAFTAR PUSTAKA}

Ahmed M, Khiati B, Djebli N, Aissat S, Maslem A, Bacha S. 2013. Potent synergism of the combination of natural honey and Peganum harmala seeds against Candida albicans ATCC 10231. Open Access Scientific Reports 2: 736. DOI: 10.4172/scientificreports736.

Ahmed M, DjebliN, Aissat S, Bacha S, Meslem A, Khiati B. 2012. Synergistic inhibition of natural honey and potato starch and their correlation with diastase number and sugar content against Klebsiella pneumoniae ATCC 27736. Nat Prod Chem Res 1: 102. DOI: 10.4172/ 2329-6836. 1000102.

Afjalus SM, Malik S, Emrul H, Sanjana S, Farjana Y. 2013. Evaluation of neuropharmacological, antibacterial and antinociceptive activity of methanolic extract of the bark of Cynometra ramiflora linn. (Leguminosae). Int $\mathrm{J}$ Res Ayurveda Pharm 4: 192-197. DOI: 10.7897/ 2277-4343.04220.

Akinnibosun, Itedjere. 2013. Evaluation of the antibacterial properties and synergistic effect of Garcinia kola heckel (Family: Guttiferae) seed extract and honey on some bacteria. Afr $\mathrm{J}$ Microbiol Res 7: 174-180.

Ado MA, Abas F, Ismail IS, Ghazali HM, Shaari K. 2014. Chemical profil and antiacetylcholinesterase, antityrosinase, antioxidant and a-glucosidase inhibitory activity of Cynometra cauliflora L. leaves. J Sci Food Agric 95: 635642. DOI: 10.1002/jsfa.6832.

Alvarez-Suarez JM, Tulipani S, Romandini S, Vidal A, Battino M. 2010. Methodological aspects about determination of phenolic compounds and in vitro evaluation of antioxidant capacity in 
the honey: a review. Curr Anal Chem 5: 292302. DOI: 10.2174/157341109789077 768.

Aziz AFA, lqbal M. 2013. Antioxidant activity and phytochemical composition of Cynometra cauliflora. J Exp Integr Med 3: 337-341. DOI: 10.5455/jeim.250813.or.086.

Bachir GR, Benali M. 2012. Antibacterial activity of the essential oils from the leaves of Eucalyptus globulus against Escherichia coli and Staphylococcus aureus. Asian Pac J Trop Biomed 2: 739-742. DOI: 10.1016/S2 221-1691(12)602202.

Bogdanov S. 2015. Honey as nutrient and functional food. Bee product sci. A Review, 1-28. http:// www.bee-hexagon. net/files/file/fileE/HealthHo ney/8HoneyNutrientFunctionalReview.pdf [15 Mei 2015].

Biesalski HK, Dragsted LO, Elmadfa I, Grossklaus R, Müller M, Schrenk D, Walter P, Weber P. 2009. Bioactive compounds: definition and assessment of activity. Nutr 25: 1202-1205. DOI: 10.1016/j.nut.2009.04.023.

Biluca FC, Betta FD, Oliveira GPD, Pereira LM, Gonzaga LV, Costa ACO, Fett R. 2014. 5-HMF and carbohydrates content in stingless bee honey by $\mathrm{CE}$ before and after thermal treatment. Food Chem 159: 244-249. DOI: 10.1016/j.foodchem.2014.03.016.

Biswas AK, Sahoo J, Chatli MK. 2011. A simple UVVis spectrophotometric method for determination of $\beta$-carotene content in raw carrot, sweet potato and supplemented chicken meta nuggets. LWT-J Food Sci Tech 44: 1809-1813. DOI: 10.1016/j.Iwt.2011.03. 017.

Britton G, Jensen SL, Pfender H. 2004. Handbook Caretonoids. 15-538. Birkhauser Verlag. Berlin. ISBN: 978-3-7643-6180-8 (book) ISBN: 978-30348-7836-4 (eBook). DOI: 10.1007/978-30348-7836-4.

Djamil R, Anelia T. 2009. Penapisan fitokimia, uji BSLT, dan uji antioksidan ekstrak metanol beberapa spesies papilionaceae. J IImu Kefarmasian Indonesia 7: 65-71.

Escuredo O, Silva LR, Valentão $P$, Seijoa MC, Andrade PB. 2012. Assessing Rubus honey value: Pollen and phenolic compounds content and antibacterial capacity. Food Chem 130: 671-678. DOI: 10.1016/j.foodchem.2011.07. 107.

Fadhilla R, Iskandar EA, Kusumaningrum HD. 2012. Aktivitas antibakteri ekstrak tumbuhan lumut hati (Marchantia paleacea) terhadap bakteri patogen dan perusak pangan. J Teknol Industri Pangan 23: 126-131. 2012. DOI: 10.6066/jtip. 2012.23.2.126.
Ferreira ICFR, Aires E, Barreira JCM, Estevinho LM. 2009. Antioxidant activity of Portuguase honey samples: Different contributions of the entire honey and phenolic extract. Food Chem 114: 1438-1443. DOI: 10.1016/j. foodchem. 2008. 11.028

Harborne JB. 1996. Metode Fitokimia Penuntun Cara Modern Menganalisis Tumbuhan. Edisi Kedua. 97-240. ITB, Bandung.

Jun M, Fu HY, Hong J, Wan X, Yang CS, Ho CT. 2003. Comparison of antioxidant activities of isoflavones from kudzu root (Pueraria labata Ohwl). J Food Sci 68: 2117-2122. DOI: 10.1111/j.1365-2621.2003.tb07029.x.

John J, Ragi RP, Sujana KA, Kumar AN. 2012. Analysis of phytochemical contents and antibacterial activity of an endangered tree (Cynometra travancorica Bedd.) of Western Ghats, India. Adv Biol Res 6: 1-5.

Kek SP, Chin NL, Yusof YA, Tan SW, Chua LS. 2014. Total phenolic contents and colour intensity of Malaysian honeys from the Apis spp. and Trigona spp. bees. Agric Agric Sci Proced 2: 150-155. DOI: 10.1016/j.aaspro. 2014.11.022.

Latuconsina NH, Fatimawali, Citraningtyas G. 2014 Uji efektivitas diuretik ekstrak etanol biji salak (Salacca Zalacca varietas Zalacca (Gaert.) Voss) pada tikus putih jantan galur wistar (Rattus norvegicus) PHARMACON J Ilmiah Farmasi 3: 177-181.

Lee H, Churey JJ, Worobo RW. 2008. Antimicrobial activity of bacterial isolatesfrom different floral sources of honey. Int J Food Microbiol 126: 240-244. DOI: 10.1016/j.ijfoodmicro.2008.04. 030.

Lestari A, Jamhari M, Kundera IN. 2013. Daya hambat ekstrak daun tembelek (Lantana camara L.) terhadap pertumbuhan bakteri Escherichia coli. E-Jip Biol 1: 42-49.

Lisiewska Z, Kmiecik W, Korus A. 2006. Content of vitamin C, carotenoids, chlorophylls and polyphenols in green parts of dill (Anethum graveolens L.) depending on plant height. J Food Compos Anal 19: 134-140. DOI: 10.1016/j.jfca.2005.04.009.

Liu X, He F, Zhao L, Zhou A, Liu X 2014. Synergistic antioxidant activity of sweet potato extracts in combination with tea polyphenols and pueraria flavonoid in vitro. Adv $\mathrm{J}$ of Food Sci Technol 6: 215-220.

Madigan MT, Martinko JM, Dunlap VP, Clark PD. 2009. Brock: Biology of Microorganisms. 12th Edition. p 794-807. Pearson Benjamin-Cummings, San Francisco. 
Maslem A, Ahmed M, Djebli N, Aissat S. 2012. Antibacterial activity of honey alone and in combination with Nigella sativa seeds against Pseudomonas aeruginosa infection. Asian Pac J Trop Dis 2: S428-S430.

Masoko P, Gololo SS, Mokgotho MP, Eloff JN, Howard RL, Mampuru LJ. 2009. Evaluation of the antioxidant, antibacterial, and antiproliferative activities of the acetone extract of the roots of Senna italica (Fabaceae). Afr J Trad CAM 7: 138-148.

Meda A, Lamien CE, Romito M, Millogo J, Nacoulma OG. 2005. Determination of the total phenolic, flavonoid and proline contents in Burkina Fasan honey, as well as their radical scavenging activity. Food Chem 91: 571-577. DOI: 10.10 16/j.foodchem.2004.10.006.

Oliver SP, Gillespie BE, Lewis MJ, Ivey SJ, Almeida RA, Luther DA, Johnson DL, Lamar KC, Moorehead HD, Dowlen HH. 2001. Efficacy of a new premilking teat disinfectant containing a phenolic combination for the prevention of mastitis. J Dairy Sci 84: 1545-1549. DOI: 10.31 68/jds.S0022-0302(01)70189-0.

Owayss AA, Rady MM, Gadallah FM. 2004. Pigmentation of some honeybee, Apis Mellifera L., products. Fayoum J Agric Res Dev 18: 121132.

Rabeta MS, Farazina R. 2013. Total phenolic content and ferric reducing antioxidant power of the leaves and fruits of Garcinia atrovirdis and Cynometra cauliflora. Int Food Res J 20: 16911696.

Ramadan MF. 2008. Total antioxidant potential of juices, beverages and hot drinks consumed in Egypt screened by DPPH in vitro assay. Grasas Y Aceites 59: 254-259. DOI: 10.3989/gya. 2008. v59.i3.516.
Ruiz AG, Cueva C, Rompinelli EMG, Yuste M, Torres M, Álvarez PJM, Bartolomé B, Arribas MVM. 2012. Antimicrobial phenolic extracts able to inhibit lactic acid bacteria growth and wine malolactic fermentation. Food Cont 28: 212-219. DOI: 10.1016/j.foodcont.2012.05. 002.

Salni, Marisa H, Mukti WR. 2011. Isolasi senyawa antibakteri dari daun jengkol (Pithecolobium lobatum benth) dan penentuan nilai KHM-nya. J Penelitian Sains 14: 1410938-1410941.

Singh R, Singh B, Kumarb N, Arora S. 2010. Antioxidant activity of triphala a combination of Terminalia chebula, Terminalia bellerica and Emblica officinalis. J Food Biochem 34: 222232. DOI: $10.1111 / \mathrm{j} .1745-4514.2009 .00$ 326.x.

Singh P, Singh S, Kapoor IPS, Singh G, Isidorov V, Szczepaniak L. 2013. Chemical composition and antioxidant activities of essential oil and oleoresins from Curcuma zedoaria rhizomes, part-74. Food Biosci 3: 42-48. DOI: 10.1016/j. fbio.2013.06.002.

Socha R, Juszczak L, Pietrzyk S, Fortuna T. 2009. Antioxidant activity and phenolic composition of herbhoneys. Food Chem 113: 568-574. DOI: 10.1016/j.foodchem.2008.08.029.

Sumarlin L, Anna M, Prita W, Masitoh. 2014. Aktivitas antikanker dan antioksidan madu di pasaran lokal Indonesia. J IImu Pertanian Indonesia 19: 136-144.

Suryanto E, Wehantouw F. 2009. Aktivitas penangkapan radikal bebas dari ekstrak fenolik daun sukun (Artocarpus altilis F.). Chem Prog 2: 1-7.

Zainol MI, Yusoff KM, Yusof MYM. 2013. Antibacterial activity of selected Malaysian honey. BMC Complemen Altern 13: 129. DOI: 10.1186/ 1472-6882-13-129. 